\title{
Use of gas analyses in modelling mineralising events in the Jameson Land Basin, East Greenland
}

Jameson Land has attracted much attention during the past century because of its potential with respect to both minerals and oil occurrences. Extensive geological investigations in particular by Lauge Koch's expeditions, Nordisk Mineselskab A/S, Atlantic Richfield Company (ARCO) and the Geological Survey of Greenland (GGU) have resulted in finds of numerous mineral occurrences and in a thorough understanding of the geological framework of the region. The Blyklippen $\mathrm{Pb}-\mathrm{Zn}$ occurrence in the Mesters Vig area (Fig. 1) is the only ore deposit that has so far been exploited; other important ore mineral concentrations include the Malmbjerget porphyry Mo deposit, the Karstryggen Sr de-

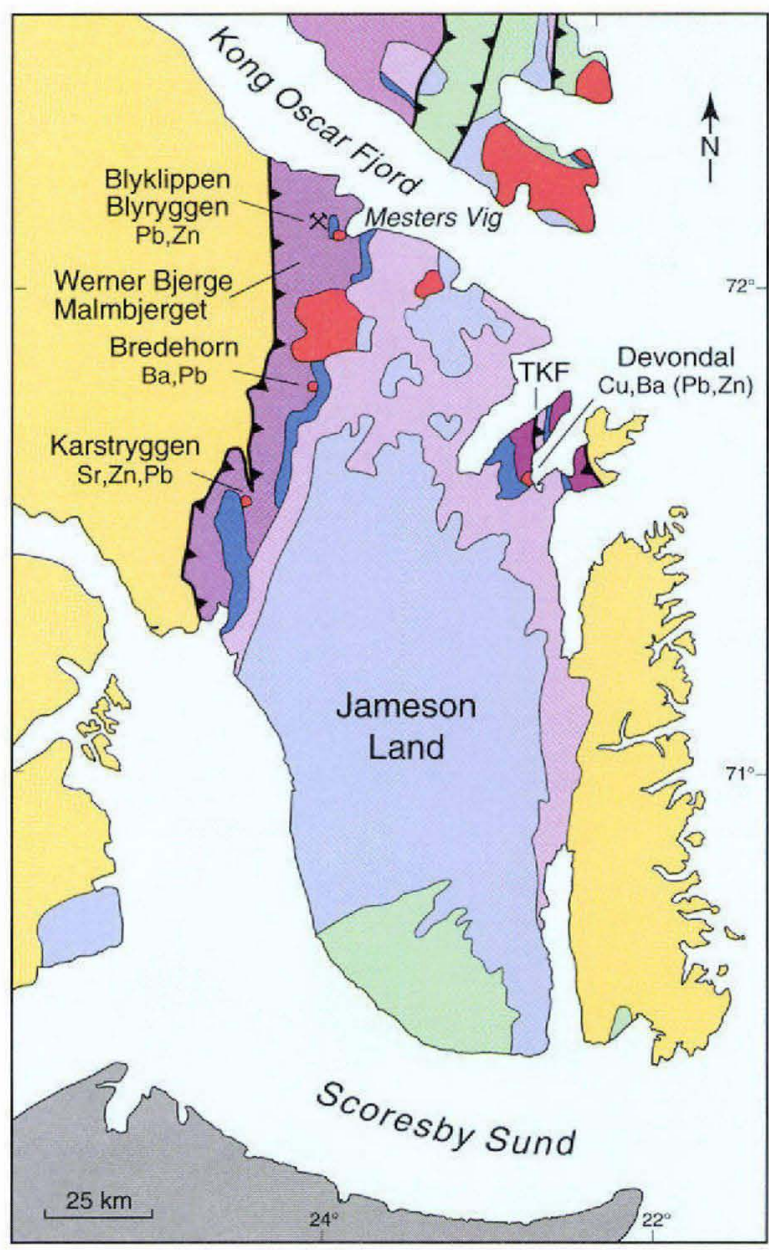

Mikael Pedersen

posit and extensive sediment-hosted $\mathrm{Pb}, \mathrm{Zn}, \mathrm{Ba}$ and $\mathrm{Cu}$ mineralisation within the region.

Until now the latter have been relatively poorly known, and in order to expand knowledge of these potentially important mineral deposits a Ph.D. project was initiated at the Survey in 1993 with support from the Danish Research Councils. The aim of the project is to increase understanding of the mineralising events with the help of lead isotope studies and various fluid inclusion analysis techniques, which will help to evaluate the mineral potential of the unexposed parts of the basin.
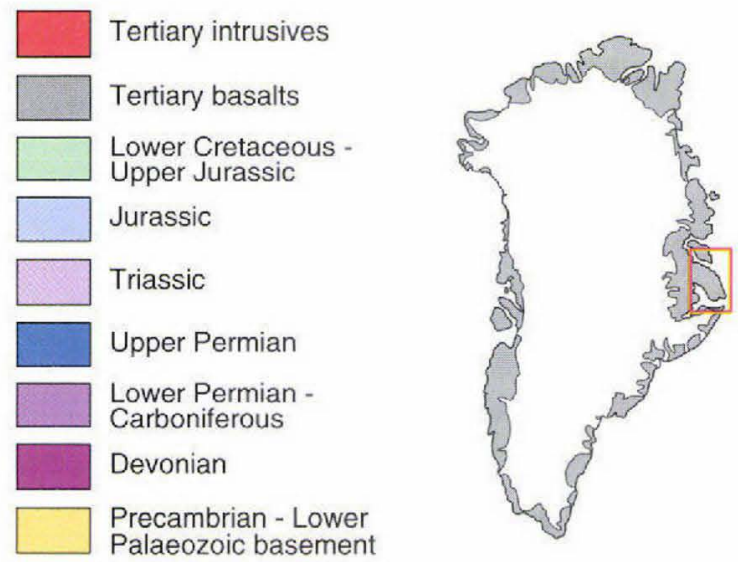

Fig. 1. Simplified geological map of Jameson Land. TKF: Tvekegledal fault. 


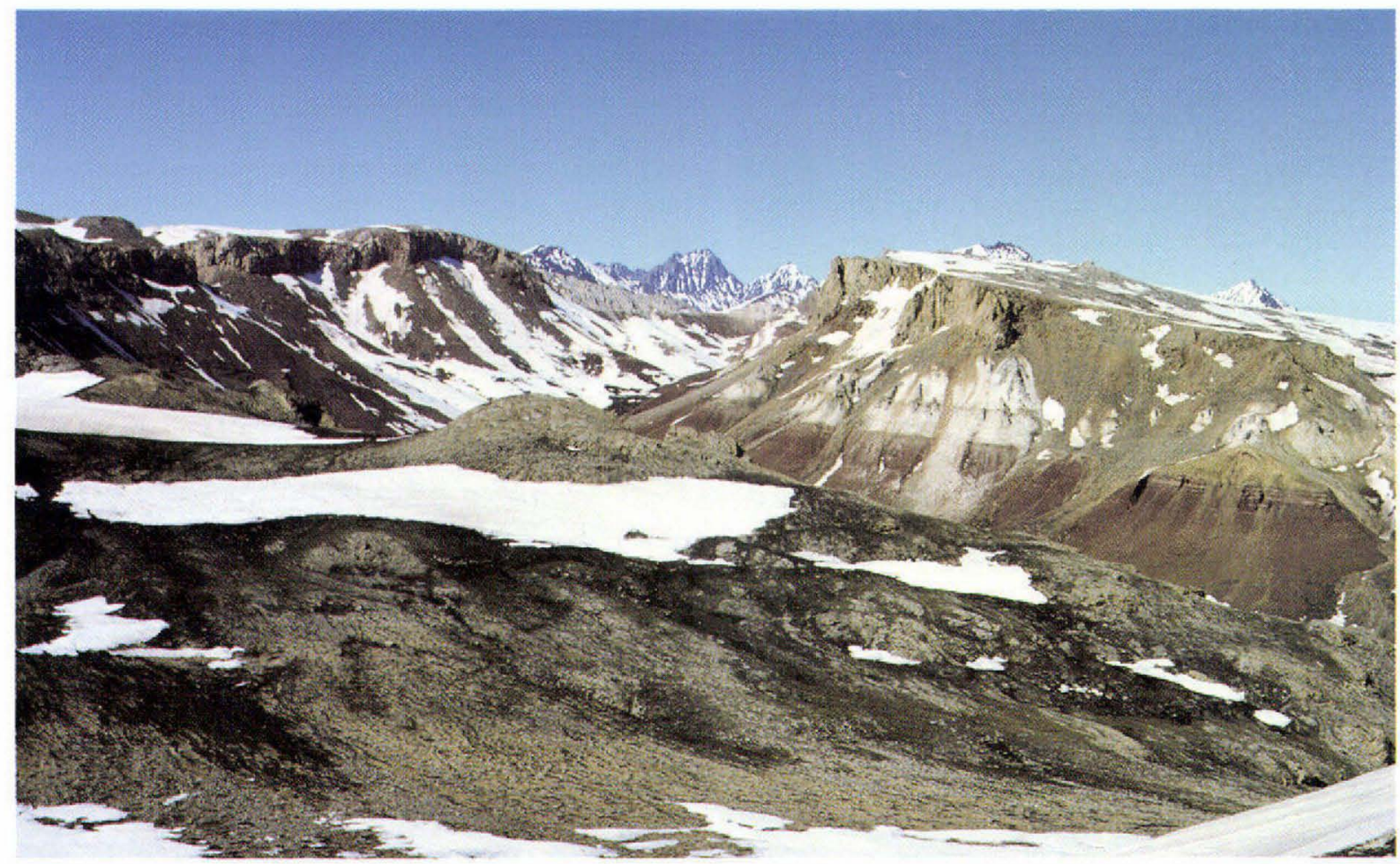

Fig. 2. View north-west over Revdal from Karstryggen. Red units are Upper Permian conglomerate (Huledal Formation), bright white units are Upper Permian gypsum lenses, and uppermost grey units are Upper Permian carbonates (Karstryggen and Wegener Halvø Formations) where the $\mathrm{Zn}-\mathrm{Pb}$ mineralisation is located.

\section{Geological overview}

The Jameson Land Basin (Fig. 1) forms the southern part of a c. $700 \mathrm{~km}$ long N-S series of sedimentary basins extending throughout the outer coastal areas of North-East and East Greenland. Basin formation was initiated in the Middle Devonian in response to extensional collapse of the over-thickened Caledonian crust (Larsen \& Bengaard, 1991). The total sedimentary sequence in the Jameson Land Basin reaches a thickness of $16-18 \mathrm{~km}$ at the basin centre (Larsen \& Marcussen, 1992). Continental sedimentation in the Devonian - Lower Permian was succeeded by marine sedimentation in the Upper Permian and deposition of alternating marine and continental deposits from the Triassic until the Upper Cretaceous. The whole area was covered by up to $2 \mathrm{~km}$ of Tertiary flood basalts during the initial opening of the North Atlantic Ocean in the Paleocene, and alkaline intrusions were emplaced in the northern part of the area later in the Tertiary (Larsen \& Marcussen, 1992; Brooks et al., this report).

Occurrences of $\mathrm{Pb}, \mathrm{Zn}, \mathrm{Ba}$ and $\mathrm{Cu}$ are concentrated in the upper parts of the $12 \mathrm{~km}$ thick succession of Devonian to Lower Permian continental clastic sediments and in the overlying Upper Permian transgressive succession (Foldvik
Creek Group). In the eastern parts of the basin Triassic deposits are also mineralised, but no mineralisation has so far been reported in younger parts of the sedimentary sequence (Harpøth et al., 1986).

\section{Mineralisation}

The project has been concentrated around four areas with different types of mineral deposits (Fig. 1):

- Fine-grained sphalerite and galena in karst-breccias in the Foldvik Creek Group at Karstryggen (Fig. 2).

- Replacement barite with associated galena in the Foldvik Creek Group at Bredehorn.

- Fault related vein-type $\mathrm{Pb}$ and $\mathrm{Zn}( \pm \mathrm{Cu}$ and $\mathrm{Ba}$ ) in $\mathrm{Up}$ per Carboniferous to Lower Permian clastic sediments at Blyryggen.

- $\mathrm{Cu}$ - and Ba-veining in the upper parts of carbonate buildups in the Foldvik Creek Group at Devondal.

These areas were visited in the summer of 1994, when systematic sampling of minerals and rocks was carried out with special reference to the different kinds of analytical work involved in the project. 


\section{Gas analysis}

Analyses of gases in inclusion fluids were undertaken at New Mexico Tech, Socorro, USA under the supervision of Prof. D. Norman, following the methods of Norman \& Sawkins (1987). Gases were extracted from the samples either by crushing or thermal decrepitation, and were analysed using a quadropole mass spectrometer.

The crushing method is quick and relatively inexpensive but allows only a small amount of gas to be measured, resulting in major uncertainties.

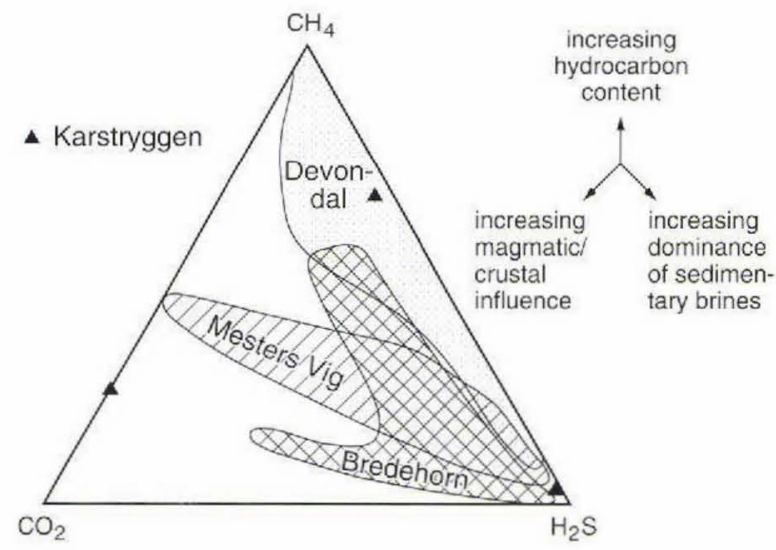

Fig. 3. Ternary plot showing the characteristics of fluid inclusion gases from Jameson Land Basin.

Thermal decrepitation has the advantage that large amounts of gas are released, and can be trapped and fractionated, allowing each fraction to be analysed separately. This is a far more precise technique; however, not all thermal effects that take place during heating can be predicted and corrected for.

In this study, quartz was most frequently used, but sphalerite, barite, fluorite, calcite and celestite were also analysed when present as sufficiently large grains. Both crushing and thermal decrepitation were undertaken, often both methods on the same sample. For statistical purposes, the values from the crushing experiments are the most usable, as more than 350 analyses have been carried out on more than 50 samples.

The gas data show that different types of fluids have been involved in ore formation (Fig. 3). Samples from Bredehorn and Blyryggen, both located near the western fault-bounded basin margin, show the influence of two fluids: a hot $\left(>250^{\circ} \mathrm{C}\right)$ component with relatively low salinity and high in $\mathrm{CO}_{2}$, and a cooler $\left(130-150^{\circ} \mathrm{C}\right)$ fluid with higher salinity and lower $\mathrm{CO}_{2}$ content. The hot fluid is interpreted as being a deep crustal fluid that has been mobilised by the intrusion of the alkaline Werner Bjerge complex, while the cooler fluid is considered to be a local sedimentary brine. The role of the Werner Bjerge complex in the generation of the hot fluid is indicated at Blyryggen, where the gas data show a trend towards higher temperatures, lower salinities and higher $\mathrm{CO}_{2} / \mathrm{N}_{2}$ ratios the closer the samples were taken to the intrusive complex. At Bredehorn, samples in general show higher $\mathrm{CO}_{2} / \mathrm{N}_{2}$ ratios than at Blyryggen, which is consistent with their position closer to the Werner Bjerge. The two-component mixing at Bredehorn and Blyryggen shown by the fluid inclusion data has also been demonstrated by lead isotope data, which suggests that lead from two different sources is present (Jensen, 1993).

The presence of two fluids with different gas components is also seen in Devondal at the eastern basin margin. One of the components is similar to the low temperature component at Blyryggen, and is interpreted as a sedimentary brine, while the other is very rich in hydrocarbons. There seems to be a geographical pattern with $\mathrm{H}_{2} \mathrm{~S} / \mathrm{CH}_{4}$ ratios increasing eastwards towards the vicinity of the Tvekegledal fault. This might indicate an increased dominance of sedimentary brine component in that direction. The hydrocarbon-rich nature of samples from the west end of Devondal can be explained by the presence of pure hydrocarbon inclusions.

According to Stemmerik (1991) liquid hydrocarbons entered the Upper Permian carbonate buildups in the Late

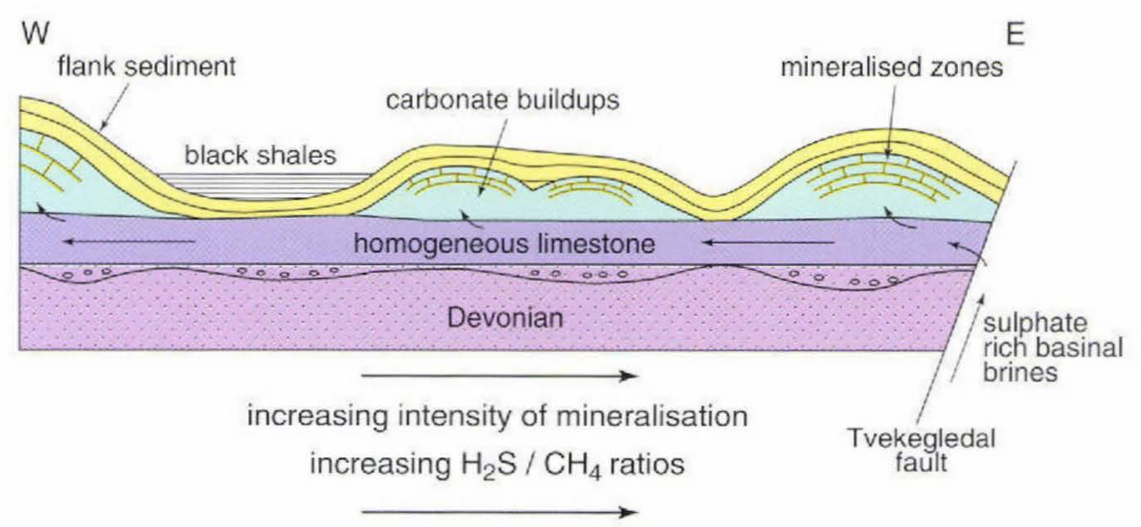

Fig. 4. Simplified model for the formation of the Devondal occurrences. 
Cretaceous, but were flushed out by ore-forming fluids in the Tertiary. The gas analyses show no evidence of $\mathrm{CO}_{2}-$ enrichment, which is seen in areas where magmatic activity has clearly played a role in ore deposition, suggesting that the mineralising fluids in Devondal are heated sedimentary brines. This is consistent with the lead isotopes that suggest a local source for the lead. Thus a model for the mineralising event in the area envisages sedimentary brines, probably enriched in $\mathrm{SO}_{4}^{2-}$ and base metals, to be mobilised by a thermal event in the Tertiary and introduced to the Devondal area along the Tvekegledal fault. The fluids then migrated laterally from the fault zone through permeable layers and some entered the overlying carbonate buildups, where hydrocarbons were already trapped (Fig. 4). The meeting between hydrocarbons and sulphate bearing brines resulted in thermochemical sulphate reduction and precipitation of sulphide minerals. The barite and quartz veining which is widespread in the area was probably formed by precipitation from cooling sedimentary brines.

At Karstryggen no suitable minerals for gas analysis were found associated with the $\mathrm{Pb}$ and $\mathrm{Zn}$ occurrences. However, some fine-grained sphalerite separated from a $\mathrm{Zn}$-rich sample, celestite from the nearby Sr-deposit and cavity-filling calcite found in the area, were analysed. Due to the fragility of all these minerals, air-contamination was a problem during the analyses, which means that $\mathrm{N}_{2}$ and $\mathrm{Ar}$ values are unreliable.

Analytical results from Karstryggen, however, suggest that the $\mathrm{Zn}-\mathrm{Pb}$ mineralisation has a gas component either derived from a magmatic or deeper crustal source, because of enrichment in $\mathrm{CO}_{2}$; the celestite and calcite show no such component. It is suggested that the $\mathrm{Zn}-\mathrm{Pb}$ occurrence was formed in close association with Tertiary lamprophyric dykes which are seen to intrude the clastic sediments below the ore zone. The celestite mineralisation, on the other hand, is related to another and probably earlier event (Scholle et al., 1990).

\section{Future work}

Further investigations on the mineral potential of the region are planned, with new fieldwork in 1996 (Stemmerik et al., this report).

\section{References}

Harpøth, O., Pedersen, J. L., Schønwandt, H. K. \& Thomasen, B. 1986: The mineral occurrences of central East Greenland. Meddr Gronland, Geoscience 17, $139 \mathrm{pp}$.

Jensen, S. M. 1993: Lead isotope composition of stratabound Cu$\mathrm{Pb}-\mathrm{Zn}-\mathrm{Ba}$ occurrences in Upper Paleozoic - Mesozoic sediments in East Greenland: In Fenoll Hach-Alí, P., Torres-Ruiz, J. \& Gervilla, F. (ed.) Current research in geology applied to ore deposits, 327-330. Granada: Universidad de Granada. (Proceedings of the Second Biennial SGA Meeting, Granada, 9-11 September 1993)

Larsen, H. C. \& Marcussen, C. 1992: Sill-intrusion, flood basalt emplacement and deep crustal structure of the Scoresby Sund region, East Greenland. In Storey, B. C., Alabaster, T. \& Pankhurst, R. J. (ed.) Magmatism and the causes of continental break-up. Spec. Publ. Geol. Soc. Lond. 68, 365-386.

Larsen, P.-H. \& Bengaard, H.-J. 1991: Devonian basin initiation in East Greenland: a result of sinistral wrench faulting and Caledonian extensional collapse. J. Geol. Soc., Lond. 148 , 355-368.

Norman, D. I. \& Sawkins, F. J. 1987: Analysis of gases in fluid inclusions by mass spectrometer. J. Chem. Geol. 61, 1-10.

Scholle, P. A., Stemmerik, L. \& Harpøth, O. 1990: Origin of major karst-associated celestite mineralization in Karstryggen, central East Greenland. J. Sed. Petr. 60, 397-410.

Stemmerik, L. 1991: Reservoir evaluation of Upper Permian buildups in the Jameson Land basin, East Greenland. Rapp. Grønlands geol. Unders. 149, $27 \mathrm{pp}$.

M. P., Geological Survey of Denmark and Greenland, Copenhagen 